\title{
PENGEMBANGAN SOAL MATEMATIKA MODEL PISA KONTEKS KAIN CUAL BANGKA BELITUNG
}

\author{
Yudi Yunika Putra ${ }^{1}$, Rajab Vebrian ${ }^{2}$ \\ ${ }^{1,2}$ STKIP Muhammadiyah Bangka Belitung. Jl. KH.A Dahlan, Mangkol, Pangkalanbaru. \\ yudi.yunikaputra@stkipmbb.ac.id
}

\begin{abstract}
This study aims to Produce PISA model mathematical problems context kain cual Bangka Belitung that meets valid, practical, and potential effect on students abilities mathematical literacy based on Basic Mathematics Ability. The subject of this research is students SMP Negeri 5 Pangkalpinang class IX.A is amounts 35 student. The research method uses design research type development study. Data were analyzed description based on criteria literacy mathematic ability based on Basic Mathematics Ability. Result this research is obtained a set of PISA mathematical problems Context kain cual Bangka Belitung is valid, practical, and potential effect on students abilities mathematical literacy. Valid obtained at stage expert review and one to one practicality is known in stages small group, and ability mathematic literacy based result analysis the answer students and questionnaire on field test stage. Based the result analysis is obtained developed problems have a potential effect on mathematical literacy abilities namely bring up the Basic Mathematical Ability.
\end{abstract}

Keywords: PISA, Mathematic, Cual Fabric, Literacy

\begin{abstract}
Abstrak
Tujuan penelitian ini adalah Menghasilkan soal matematika model PISA Konteks Kain Cual Bangka Belitung yang memenuhi kriteria valid, praktis, efek potensial terhadap Kemampuan Literasi Matematika Siswa berdasakan Kemampuan Dasar Matematika (KDM). Subjek penelitian ini adalah siswa SMP Negeri 5 Pangkalpinang kelas IX.A yang berjumlah 35 siswa. Metode penelitian menggunakan design research tipe development study. Data dianalisis secara deskriptif berdasarkan kriteria kemampuan literasi matematis berdasarkan Kemampuan Dasar Matematika (KDM). Hasil penelitian didapatkan seperangkat soal matematika model PISA Konteks Kain Cual Bangka Belitung yang valid, praktis, dan memiliki efek potensial terhadap kemampuan literasi matematika siswa.Valid didapatkan pada tahap expert review dan one to one, small group, dan kemampuan literasi matematis berdasarkan hasil analisis jawaban siswa dan angket pada tahap field test. Berdasarkan hasil analisis didapatkan bahwa soal yang dikembangkan memiliki efek potensial terhadap kemampuan literasi matematis, yaitu memunculkan Kemampuan Dasar Matematis.
\end{abstract}

Kata Kunci: PISA, Matematika, Kain Cual, Literasi.

Keterampilan literasi matematika sangat penting dimiliki oleh semua orang karena salah satu peningkatan produk domestik bruto (PDB) yaitu dapat diperoleh dengan memastikan bahwa semua siswa saat ini memiliki keterampilan dasar saat lulus (yang ditunjukkan melalui skor PISA 420) dan memfasilitasi pendidikan dan pelatihan bagi orang dewasa akan meningkatkan stok keterampilan dengan lebih cepat (OECD; 2018). Sehingga sangat diharapkan dalam pembelajaran matematika siswa dibiasakan untuk menyelesaikan permasalahan kedalam konteks keseharian secara matematis. Pentingnya kemampuan literasi matematika tidak serta merta diikuti dengan hasil studi PISA (Programme for International Student Assesment). Pada penilaian pada PISA tahun 2015 Indonesia menempati peringkat 62 dari 70 negara peserta (OECD, 2016b), meskipun ada peningkatan dari penilaian tahun 2012 yang menempati peringkat 64 dari 65 negara (OECD, 2014a) nilai siswa Indonesia masih dibawah rata-rata peserta OECD. Sedangkan kompetensi matematika mengalami peningkatan 
pada penilaian PISA tahun 2012 sebesar 275 poin menjadi 386 poin pada penilaian tahun 2015, tetapi hasil PISA tahun 2015 masih rendah dibandingkan rerata OECD (Kemendikbud.go.id; 2016).

Aspek penting dari literasi matematika adalah bahwa matematika terlibat dalam memecahkan permasalahan konteks, konteksnya adalah aspek dunia individu dimana masalah ditempatkan (OECD, 2013). Sehingga sangat baik apabila dalam pembelajaran menggunakan soal-soal literasi yang dikaitkan dengan konteks keseharian siswa. Seperti yang disampaikan oleh Charmila, Zulkardi, \& Darmawijoyo (2016) bahwa soal konteks mampu menarik minat dan memotivasi siswa sehingga tertantang menyelesaikan soal, dan memberikan stimulus kepada siswa untuk berpikir kritis menggunakan penalaran sendiri dalam penyelesaiannya. Selain itu, soal menggunakan konteks akan mempermudah siswa dalam mensituasikan matematika kedalam konteks sehingga akan membantu siswa dalam menggunakan kemampuan literasi dalam menjawab soal, dan dapat menantang pola berpikir matematis (Putra, Zulkardi, \& Hartono, 2016).

Berdasarkan penelitian sebelumnya, beberapa penelitian telah dilakukan dalam mengembangkan soal matematika model PISA (Fatmawati, 2016; Putra, Zulkardi, \& Hartono, 2016; Silva, Zulkardi, \& Darmawijoyo, 2013) dari penelitian tersebut hanya berfokus pada salah satu konten, sedangkan konten dalam matematika PISA ada 4 konten dan penelitian tersebut tidak langsung ke konteks yang sering ditemui oleh siswa Sedangkan penelitian tentang soal matematika model PISA kontekstual (Charmila, Zulkardi, \& Darmawijoyo, 2016; Oktiningrum, Zulkardi, \& Hartono, 2016; Putra, Zulkardi, \& Hartono, 2016). Dari penelitian tersebut belum menggunakan konteks Bangka,tetapi ada satu penelitian tentang PISA konteks Bangka (Dasaprawira, 2019). Dalam penelitian tersebut menggunakan konteks mecusuar tanjung kalian, sedangkan penelitian menggunakan kain tapis Bangka Belitung. Sehingga penelitian ini bertujuan untuk Menghasilkan soal matematika model PISA Konteks Kain Cual Bangka Belitung yang valid, praktis, dan melihat Kemampuan Literasi Matematika Siswa.

\section{METODE PENELITIAN}

Metode penelitian menggunakan Design research dengan tipe development study. Tahap pengembangan menggunakan dua tahap yaitu persiapan (preliminary) dan tahap prototyping (Zulkardi, 2002). Pada tahap prototyping menggunakan alur formative evaluation (Tessmer, 1998) yang terdiri dari beberapa tahapan yaitu self evaluation, prototyping (expert review, one-to-one, dan small group), dan field test. Subjek penelitian adalah siswa kelas IX SMP Negeri 5 Pangkalpinang yang berusia maksimal 15 tahun. Pemilihan subjek berusia 15 tahun berdasarkan kriteria penilaian PISA dan dilakukan di Pangkalpinang karena dalam pengembangan ini menggunakan konteks kain cual Bangka Belitung yang merupakan kain khas daerah siswa dan Pangkalpinang merupakan Ibukota propinsi sehingga tidak akan terjadinya bias dalam pengambilan data pengembangan.

Teknik pengumpulan data berupa dokumentasi, tes tertulis, wawancara, dan kuesioner. Dokumentasi berupa data tentang hasil penelitian berupa foto-foto kegiatan, saran atau komentar dari 
validator dan siswa, dan hasil jawaban siswa. Dokumentasi didapatkan pada setiap tahapan. wawancara didapatkan pada saat one-to-one dan small group yang berfokus pada perbaikan prototype. kuesioner diberikan pada tahap small group yang berfokus pada kepraktisan dan tahap field test berfokus pada efek potensial. Data dianalisis secara deskriptif untuk mendapatkan data tentang kevalidan, kepraktisan, dan efek potensial pada masing-masing tahapan. Jadi dapat disimpulkan bahwa kevalidan didapatkan pada tahap expert review dan one-to-one, kepraktisan pada tahap small group, dan efek potensial pada tahap field test.

\section{HASIL PENELITIAN DAN PEMBAHASAN}

Hasil dari pengembangan menghasilkan prototype berupa perangkat soal matematika model PISA menggunakan konteks kain cual Bangka Belitung yang memenuhi kriteria valid, praktis, dan memiliki efek potensial terhadap kemampuan literasi matematika siswa berdasarkan kemampuan dasar matematika (KDM). Penelitian ini melalui dua tahap yaitu preliminary dan prototyping yang meliputi self evaluation, expert review dan one-to-one, small group, field test. Pada tahap Persiapan (preliminary) dilakukan analisis tentang kurikulum Sekolah Menengah Pertama (SMP), Analisis konteks kain cual Bangka Belitung yang bisa dijadikan soal, mengkaji framework PISA, dan beberapa literatur tentang penelitian PISA. Pada tahap ini dihasilkan prototype awal berupa perangkat soal matematika model PISA menggunakan konteks kain cual Bangka Belitung. Pada tahap ini juga menentukan tempat penelitian, subjek dan mengatur jadwal penelitian.

Setelah dihasilkan prototype awal pada tahap preliminary dilanjutkan tahap formative evaluation. Tahap pertama yang dilakukan adalah self evaluation dengan menelaah kembali desain prototype awal berdasarkan kerangka framework PISA yang dilakukan peneliti dan divalidasi oleh teman-teman sejawat baik dari segi konten, konstruk, dan bahasa.

Langkah selanjutnya adalah expert review dan one-to-one yang dilakukan secara paralel. expert review atau ahli memvalidasi prorotype dari segi konten, konstruk, dan bahasa. Konten berdasarkan kurikulum matematika di Sekolah Menengah Pertama (SMP), konstruk berdasarkan framework PISA, dan bahasa berdasarkan dengan kaidah bahasa yang baik (EYD). Masukan dari expert review dijadikan bahan untuk merevisi prototype agar lebih baik. Pada penelitian ini expert review melibatkan guru besar pendidikan matematika Universitas Negeri Padang (UNP) dan Dosen Pendidikan Matematika Universitas Pendidikan Indonesia (UPI). Pakar pertama memberikan komentar tentang pemilihan Kemampuan Dasar Matematika (KDM) setiap soalnya diambil sebagian saja tidak perlu semuanya, kecuali kalau siswa diminta untuk menulis proses jawaban, dan rubrik penskoran dibuat secara deskriptif. Sedangkan pakar kedua memvalidasi seluruh soal dengan memberikan komentar tentang konstruksi soal.

Pada tahap expert review secara paralel juga dilakukan tahap one-to-one. Pada tahap ini berkaitan langsung dengan subjek penelitian. Subjek penelitian pada tahap one-to-one berjumlah 3 
orang masing-masing memiliki kemampuan rendah, sedang, dan tinggi. Pada tahap one-to-one masingmasing siswa diberikan soal untuk mencermati, membaca, dan mengerjakan soal tersebut. Pada tahap ini dianalisis secara rinci tentang prototype apakah soal yang dikembangkan sulit dipahami oleh siswa karena ketidaksesuaian perangkat soal. Hasil analisa expert review dan one-to-one dijadikan bahan untuk merevisi prototype untuk dilanjutkan pada tahap small group. Sehingga didapatkan prototype yang memenuhi kriteria valid.

Pada tahap small group berjumlah 6 orang dengan masing-masing dua orang memiliki kemampuan rendah, sedang, dan tinggi. Pada tahap ini seluruh siswa secara berkelompok mendiskusikan prototype untuk mengkaji tentang kepraktisan prototype. Masukan dan komentar siswa pada tahap ini dijadikan bahan untuk merevisi prototype untuk dilanjutkan pada tahap field test. Pada tahap ini subjek juga diberikan angket untuk melihat kepraktisan soal.

Tahap field test, prototype yang sudah memenuhi kriteria valid dan praktis diujicobakan pada satu kelas yang berjumlah 35 siswa kelas IX.A SMP Negeri 5 Pangkalpinang. Tahap field test dilaksanakan pada semester ganjil tahun ajaran 2019/2020. Hasil field test berupa lembar jawaban siswa yang dianalisis secara deskriptif berdasarkan penskoran yang dibuat dengan kriteria kemampuan literasi matematis berdasarkan Kemampuan Dasar Matematika (KDM) dan hasil angket dianalisis secara deskriptif berdasarkan KDM dan temuan-temuan yang didapatkan. Pada soal di bawah ini merupakan soal matematika model PISA menggunakan konteks kain cual Bangka Belitung.Pada soal konteks kain cual ini terdapat 4 (empat) pertanyaan yang diberikan kepada subjek field test.

\section{Informasi Umum Soal No 1 dan 2}

Gambar di bawah ini merupakan potongan Kain Cual yang merupakan kain tenun tradisional khas Provinsi Kepulauan Bangka Belitung. Kata "cual" dalam bahasa setempat berarti celupan benang pada proses awal, ciri khas kain ini terletak pada teknik tenun yang menggabungkan antara teknik sungkit dan tenun ikat.

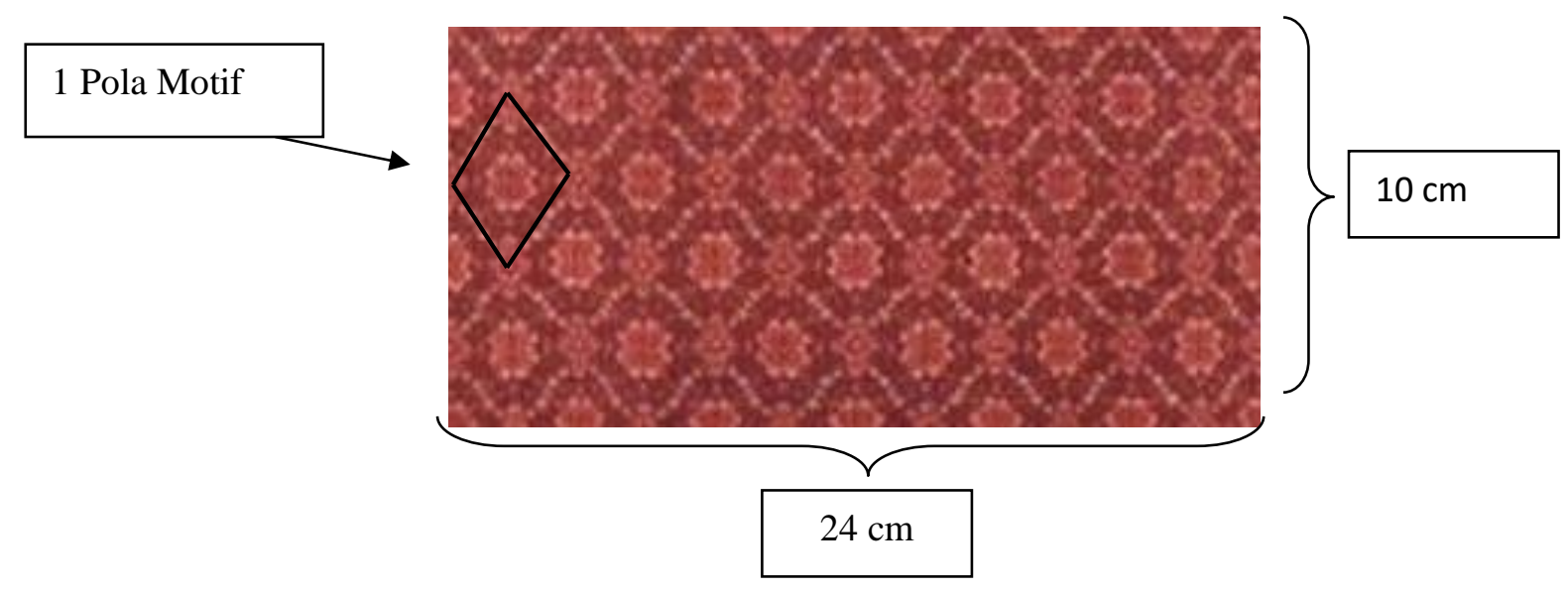

Gambar 1. Motif Kain Cual 


\section{Soal No 1}

Pada gambar 2 motif kain Cual terdapat 22 pola motif utuh dengan ukuran panjang $24 \mathrm{~cm}$ dan lebar 10 $\mathrm{cm}$. Membentuk berapa banyak pola motif utuh apabila panjang potongan kain panjang $48 \mathrm{~cm}$ dan lebar $20 \mathrm{~cm}$ ?

Hasil analisis jawaban siswa didapatkan data bahwa sebanyak 35 siswa dalam menjawab soal no 1 semuanya memberikan argumentasinya. Dengan skor yang didapatkan oleh 35 siswa mendapatkan nilai 60 dengan skor maksimal 140, atau mendapatkan nilai 42,9 dengan rentang 100, dengan rincian 35 siswa yang menjawab tepat sebanyak 6 siswa. Nilai tersebut merupakan kategori yang cukup. Semua siswa merasa kesulitan dalam mengerjakan soal tersebut, dikarenakan prediksi level yang tinggi yaitu 5.

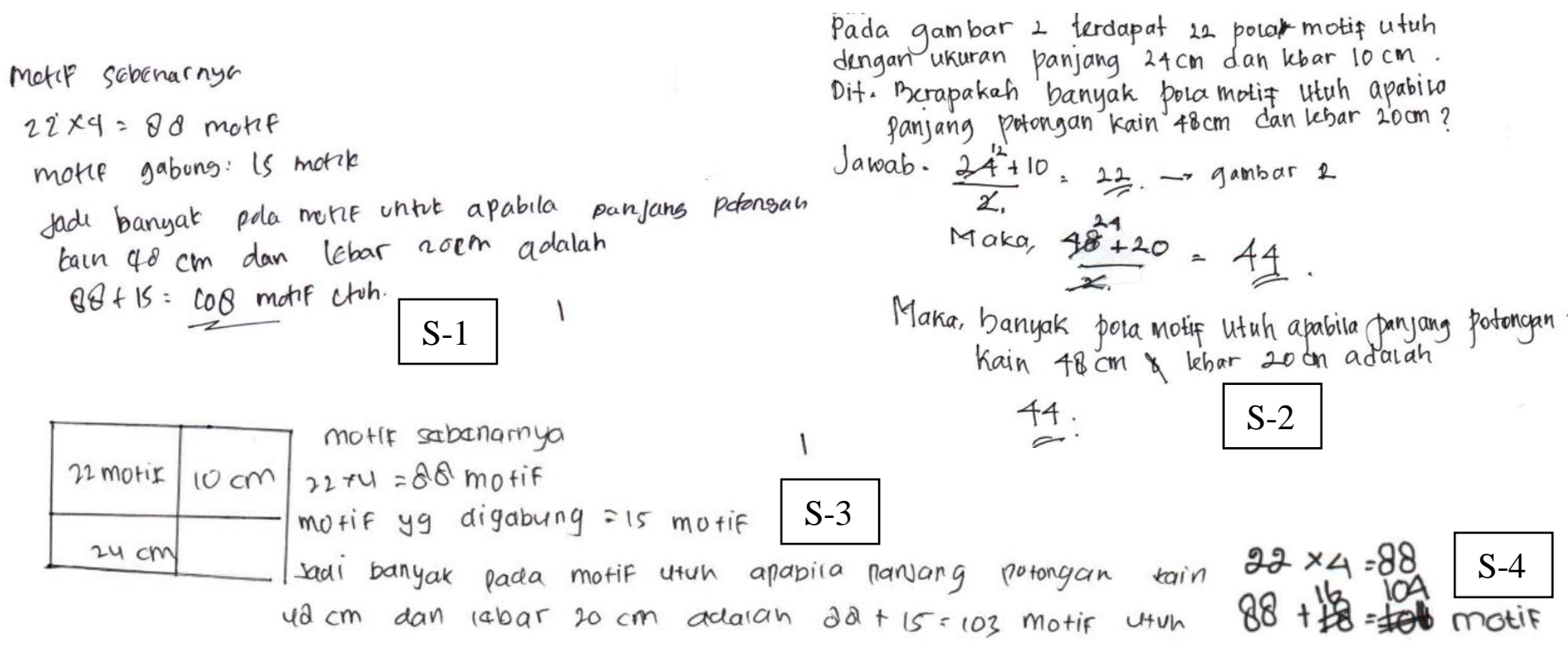

\section{Gambar 2. Jawaban Siswa Soal No 1}

Berdasarkan deskripsi soal no 1 ini berkaitan dengan pokok bahasan bilangan dan pokok bahasan bangun datar persegi panjang. Dalam menjawab soal seseorang harus mampu mengaitkan bentuk motif kedalam bilangan sesuai dengan konsep luas bangun datar persegi panjang. Kesalahan terbesar siswa dalam menjawab soal adalah tidak mengaitkan bentuk motif kedalam luas kain yang ditanya. Sebenarnya S-1 sudah tepat dengan menambah motif gabungannya, tetapi kurang teliti melibatkan indikator operasi simbolik dalam menghitung banyak motif utuh yang telah tergabung menjadi utuh, seharusnya jawabannya adalah $88+16$ tetapi S-1 hanya menambahkan 88 dengan 15 , dan S-1 juga tidak tepat dalam melakukan penjumlahan.

Berbeda dengan subjek S-2 kurang tepat dalam menerjemahkan motif kain cual kedalam bentuk bilangan, S-2 menganggap bahwa soal tersebut diselesaikan dengan menggunakan perbandingan, 
padahal tidak. S-2 tidak mampu melibatkan kemampuan penalaran dan argumentasi dalam menggunakan konsep luas persegi panjang berdasarkan motif utuh yang terbentuk, sehingga tidak mampu menggunakan indikator kemampuan dasar matematika (KDM) yang lainnya.

Sedangkan subjek S-3 sudah mampu menggunakan kemampuan penalaran dan argumentasi dalam menjawab soal dengan menggunakan konsep luas persegi panjang berdasarkan motif utuh yang terbentuk, hanya saja kurang teliti dalam menjumlahkan banyaknya motif utuh yang tergabung, seharusnya 16 tetapi S-3 hanya menjumlahkan dengan 15 . Sebenarnya S-1 dan S-3 sama dalam menjawabnya, perbedaannya terletak pada penjumlahannya, S-3 tepat dalam mengopersaikan penjumlahan. Subjek S-4 sudah tepat dalam menentukan hasil akhir dengan menjumlahkan semua motif yang terbentuk dari luas kain yang ditanya.

Berdasarkan Kemampuan Dasar Matematika (KDM) yang dilibatkan siswa dalam menjawab soal, dapat disimpulkan bahwa soal no 1 ini memiliki efek potensial terhadap kemampuan literasi dalam penggunaan kemampuan dasar matematika pada indikator, penalaran dan argumentasi, komunikasi, matematisasi, strategi pemecahan masalah, dan bahasa dan operasi simbolik.

\section{Soal No 2}

Pada gambar 2 motif kain Cual dengan ukuran $24 \mathrm{~cm} x 10 \mathrm{~cm}$, berapakah simetri putar dan simetri lipat yang terbentuk dengan ukuran tersebut? Jelaskan argumentasimu!

Hasil analisis jawaban siswa didapatkan data tidak ada sama sekali siswa menjawab dengan benar. Dari 35 siswa hanya mendapatkan skor 10,7 dengan rentang 100. Sebanyak 20 siswa tidak menjawab dan 15 siswa menjawab namun tidak sampai pada akhir jawaban.

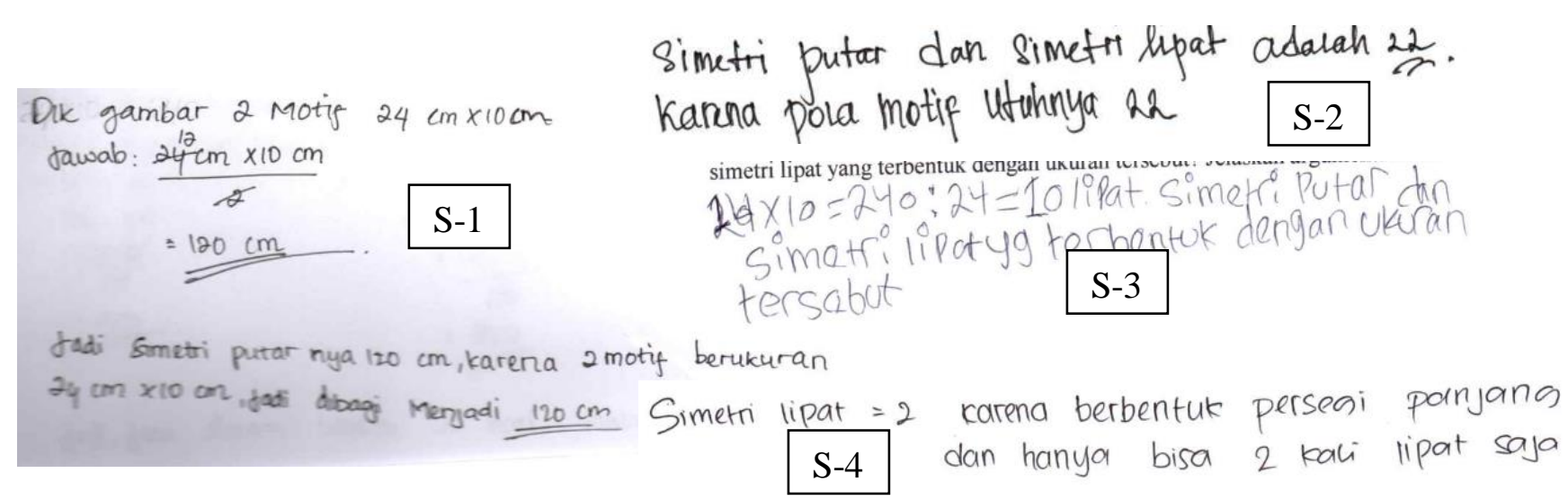

Gambar 3. Jawaban Siswa Soal No 2

Soal no 2 ini berkaitan dengan konsep simetri lipat dan simetri putar. Dalam menjawab soal hal pertama yang dilakukan adalah memahami bentuk motif kain cual bukan bentuk bangun datarnya. Motif kain cual tersebut ada motif yang utuh dan motif yang terpotong. 
Semua subjek lupa dengan materi simetri putar dan simetri lipat, sehingga tidak tepat dalam menjawab, ini menemukan data bahwa ilmu matematika saling berkaitan, ini membuktikan ilmu matematika tidak mesti harus dihapal tetapi perlu dipahami akan konsep tersebut. Sehingga ditemukan data bahwa individu yang membiasakan menghafal tentang materi matematika seperti simetri lipat dan simetri putar saat pembelajaran akan lupa pada waktu tertentu saat mengulang pembelajaran tersebut, sedangkan bagi yang memahami atas konsep tersebut akan mengingatnya kembali meskipun sudah tidak belajar.

Keterampilan rendah menghambat pertumbuhan penduduk. Hasil PISA 2015, yang menunjukkan bahwa sekitar tiga per empat anak usia 15 tahun siswa Indonesia tidak memiliki keterampilan dasar matematika, dan kurang dari sepertiga anak memiliki kemampuan membaca dasar (OECD, 2016c).

\section{KESIMPULAN}

Berdasarkan hasil penelitian dan pembahasan dapat disimpulkan bahwa soal matematika model PISA menggunakan konteks kain cual Bangka Belitung yang dikembangkan telah memiliki kriteria valid dan praktis. Valid berdasarkan saran dari ahli pada tahap expert review yang telah digabungkan dengan komentar subjek one-to-one. Sedangkan praktis didapatkan berdasarkan saran dari siswa subjek small group dimana semua subjek dapat memahami soal tersebut.

Dalam pembelajaran sangat penting menggunakan soal-soal PISA menggunakan konteks keseharian siswa. Sehingga soal-soal matematika model PISA menggunakan konteks keseharian siswa sangat diperlukan untuk menunjang kemampuan literasi matematika siswa, selain itu siswa dibiasakan untuk menyelesaikan permasalahan konteks keseharian kedalam soal agar siswa terbiasa menyelesaikannya permasalahan secara matematis. Permasalahan saat ini guru kekurangan kompetensi yang diperlukan, dan juga kekurangan dukungan, sementara ketidakhadiran guru masih menjadi masalah (OECD, 2016a).Sehingga soal yang dikembangkan ini dapat dijadikan acuan oleh guru untuk menggunakan dalam pembelajaran atau untuk mendesain soal yang serupa.

\section{DAFTAR PUSTAKA}

Charmila, N., Zulkardi, Z., \& Darmawijoyo, D. (2016). Pengembangan soal matematika model PISA menggunakan Konteks Jambi. Jurnal Penelitian dan Evaluasi Pendidikan, 20 (2), 198-207.

Dasaprawira, M. N. (2019). Developing Mathematics Questions of PISA Type Using Bangka Context. Journal on Mathematics Education, 10(2), 303-314.

Fatmawati, D. (2016). Pengembangan soal matematika pisa like pada konten change and relationship untuk siswa sekolah menengah pertama. MATHEdunesa, 5(2).

Kemendikbud. (2016). Peringkat dan Capaian PISA Indonesia Mengalami Peningkatan. Diakses dari https://www.kemdikbud.go.id pada 12 September 2019. 
OECD (2016a), OECD Economic Surveys: Indonesia 2016, OECD Publishing, Paris, http://dx.doi.org/10.1787/eco_surveys-idn-2016-en.

OECD (2016c), PISA 2015 Results (Volume I):Excellence and Equity in Education, PISA, OECD Publishing, Paris, http://dx.doi.org/10.1787/9789264266490-en.

OECD (2018), Survey Economi OECD Indonesia, OECD Publishing, Paris.

Oktiningrum, W., Zulkardi, \& Hartono, Y. (2016). Developing PISA-like Mathematics Task with Indonesia Natural and Cultural Heritage as Context to Assess Studentse Mathematical Literacy. Journal on Mathematics Education, 7 (1), 1-8.

Putra, Y. Y., Zulkardi, Z., \& Hartono, Y. (2016). Pengembangan Soal Matematika Model PISA Konten Bilangan untuk Mengetahui Kemampuan Literasi Matematika Siswa. Jurnal Elemen, 2(1), 14-26.

Putra, Y. Y., Zulkardi, Z., \& Hartono, Y. (2016). Pengembangan Soal Matematika Model PISA Level 4, 5, 6 Menggunakan Konteks Lampung. Kreano, Jurnal Matematika Kreatif-Inovatif, 7(1), 10-16.

Silva, E. Y., Zulkardi, Z., \& Darmawijoyo, D. (2013). Pengembangan soal matematika model PISA pada konten uncertainty untuk mengukur kemampuan pemecahan masalah matematika siswa sekolah menengah pertama. Jurnal Pendidikan Matematika, 5(1).

Tessmer, M. (1993). Planning and Conducting Formative Evaluations: Improving the Quality of Education and Training. London: Kogan Page.

Zulkardi. (2002). Developing a learning on realistic mathematics education for Indonesian students teachers. Doctoral Dissertation.Enschede: University of Twente. 